\title{
Social Conflict and Women Vulnerability in East Java 2016-2018
}

\author{
M Noviryani', M R Hanafi ${ }^{2}$, A C Fahadayna ${ }^{3}$ \\ $1,2,3$ Universitas Brawijaya, Malang \\ ${ }^{1}$ melynovi@gmail.com ${ }^{2}$ rizahanafi@gmail.com ${ }^{3}$ fahadayna@gmail.com
}

\begin{abstract}
This study aimed to create a conflict database in East Java that classified by gender-related conflict. It identified the trend of social conflict in East Java and how the conflicts affect women vulnerability. This study demonstrated women involvement in conflict, whether they act as perpetrators, victims, or peacemakers. The limitation of the latest dataset and requirement of the data that classified conflict based on gender is the primary urgency of the research. This study used media monitoring for data collection method. Conflicts are categorized in five categories : natural resources, economic resources, electoral, identity, governance and others. The outcome of the research are expected to become recommendation for policymakers that already required by Law No.7/2012 and President Regulation No. 18/2014 to encourage all stakeholders to take action plans or policies to respond conflicts with gender perspectives.. These regulations follows the mandate of the UN Resolution No. 1325 that ratified on October 31,2010, which asserts the importance of specific policy to ensure the absence of gender-based violence during the conflict and promotes women's role in conflict prevention and resolution. This study exhibits that social conflict in East Java showed an increasing trend, as well as women's involvement in the conflict, although not comprehensively reported by the media. The role of women as peacemakers dominated by those who are victims. This study also found the potential of women from the government sector as peacemakers.
\end{abstract}

Keywords: Conflict, violence, East Java, Women.

\section{INTRODUCTION}

East Java is the province with a high conflict vulnerability level. Based on the data that summarized from National Violence Monitoring System (NVMS), it could be said that East Java, especially in the eastern part of Java, already happened 3446 social conflicts during 2011-2015.[1] The most intense conflicts in East Java were happened in 2011-2012, with the detail between 975 and 927 incident, and the lowest intensity of conflict was in 2015 with 160 incidents. 
Picture 1: Conflict in Indonesia 2011-2015

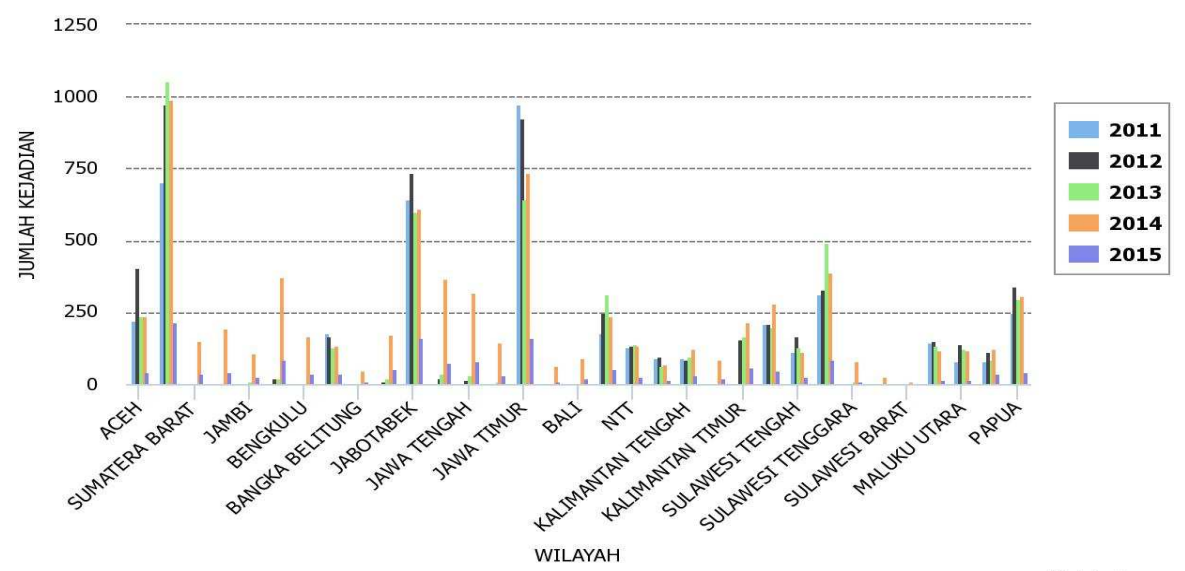

Source: Data processed through NVMS

However, this does not directly indicate a decline, since the NVMS data collection was stopped in 2015. This was also strenghthened by comparing East Java with other province at the same year. East Java still on the third position as province with the highest number of social conflict, after North Sumatra with 216 incidents and Greater Jakarta with 162 incidents.[1]

Picture 2: Conflict in Indonesia in 2015

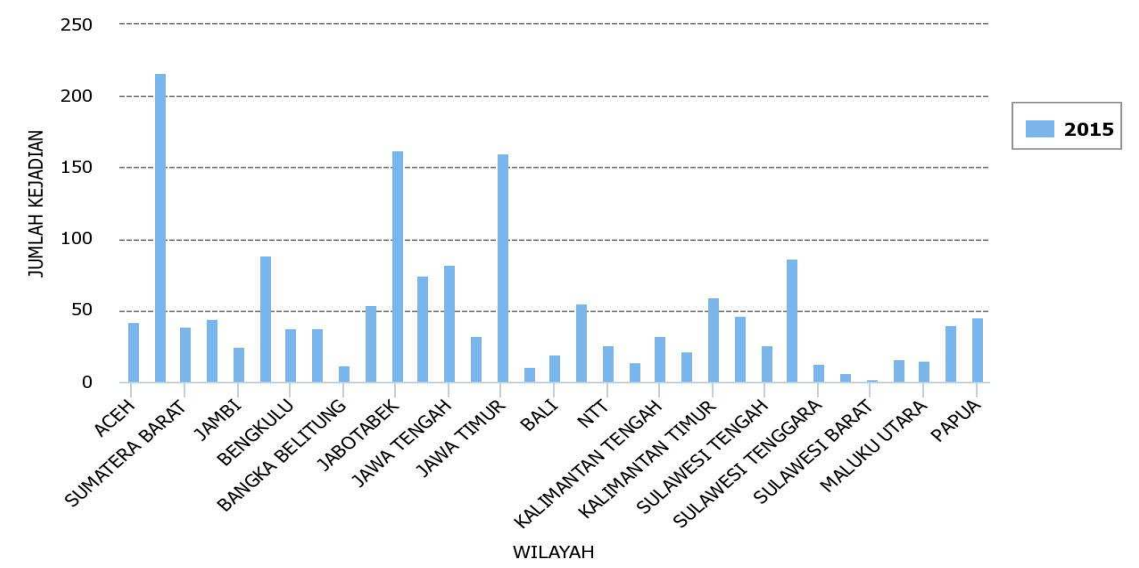

Source : Data processed through NVMS

In terms of minority rights protection, East Java has a fairly poor record. Since 2015, the democracy index indicated of East Java continues to decline.[2] The government of East Java is the party that give reckless respond to Ahmadiyya community through Governor Decree No. 188/94/KPTS/013/2011 which prohibits any Ahmadiyya community's activities in all areas of East Java.[3] The East Java Government has also tolerated violence against the 
Shia community in Sampang Madura since 2011.[3] The 2016 Human Rights Commission data reviewed many complaints about violence and human rights violations related to freedom of religion and belief.[3]

NVMS itself is the integrative monitoring system that updated realtime by the Coordinating Ministry for Human Development and Cultural Affairs. NVMS launched in 2014 and expected to become a reference for analyzing and mapping violence and conflict in Indonesia. The methods used in NVMS are media monitoring that focused on the news about violence and conflict that reported in national and local newspaper agencies, and also equipped by data from a government report, NGO report, and academic report. It covers 34 provinces with a timeframe around 1998-2015 and always updated every month and presented through the raw dataset, graphics also four-month report.

The problem with NVMS is the gender perspective that missed from the reports and analysis. Thus, it can be concluded that the report on violence and conflicts exclude women from the context of conflict while women are the most vulnerable parties in conflict. There is a tendency of women to become targets of violence as the manifestation of conquest and weaken toward enemies. Thus, it is crucial for mainstreaming gender perspectives to avoid women's vulnerability and encourage women to be more contributive as peace agents.

One global instrument that integrates a gender perspective in conflict resolution is UN Security Council Resolution 1325/2000 which provides guidance from the stages before, during and after the conflict.[4] This resolution recognizes the great impact of conflict on women specifically related to the gender-based violence, and also encourages women participation in conflict prevention and resolution. Indonesia as one of the signatory countries of this resolution already has legal instruments to govern social conflict. The Law No. 7/2012 governs Social Conflicts Handling which also regulates the fulfillment of women's rights in conflict.[4] There is also Presidential Regulation No.18/2014 concerning Protection and Empowerment of Women and Children in Social Conflict.[5]

In 2015, the Governor of East Java also issued Decree No. 188/238 / KPTS / 013/2015 concerning the East Java Province Integrated Social Conflict Handling Team, which assigned starting from coordinating supervision, responding and taking quick actions, provide an explanation to the public and report the development of social conflict and its handling.[6] However, There is no representative of the state agency that deals with gender issues, such as the Women's Empowerment and Child Protection Agency, involved in this team.[6]

This study aims to look at the trend of social conflict and women vulnerability in East Java and find out the role of women in conflict resolution throughout 2016-2018. The findings are expected to become input for policy making in conflict handling mechanism with gender perspectives

\section{RESEARCH METHOD}

The research used media monitoring at the national and local levels as main method. Limited access to print media made this research used online news portals for data collection that was obtain from kompas.com, Jawa Pos Group, Tribune Group, Berita Jatim, and Times Indonesia. The first three media were used based on their wide national and regional coverage. The latest two media were used because they are based in East Java and have been verified by the Press Council. Media monitoring is defined as the process of reading, watching or listening to editorial content from media sources, then identifying, storing and analyzing its content according to certain topics or keywords.[7] The keywords used to search data are 
terminologies that commonly used by online media to describe conflicts in the news collected by NVMS in previous periods.

Practically, conflict is interpreted as something that intersect with many aspects such as actors, dynamics and context.[8] Thus conflict is a complex phenomenon that must be viewed from various perspectives. There are some tools needed in analyzing conflicts, including to see the cause and effect-both directly and indirectly, intervening variables, and the consequences of conflict. Social conflict can simply understood as expressed by Robert Park and Ernest Burgess, who defines conflict as a struggle for status.[9] This status can be interpreted as social status, status of existence and welfare status. Mack and Snyder defined conflict not only about struggle for status but also about fight for the limited resource or manifestation of significant social change.[10] Berger and Luckmann provide a "common thread" in understanding social conflict as conflict that occurs due to social interactions that occur daily.[11] Conflict is always rooted in simple problems that involve human life in their daily lives. Even in seeing the subject of conflict often involves parties who are emotionally and geographically proximity. Conflict could also mobilized politically in order to achieve some political goals that could produce structural violence and trigger a more repressive society that people unaware of the condition of the conflict itself, justified by political means and also executed by state apparatus.[12]

In this study, social conflicts are then categorized as follows: a. Natural Resource Conflict, refers to conflicts over ownership, access, decision making on management, distribution of benefits and the burden of managing natural resources such as oil, land, minerals, forests, water, that exists in nature and can be exploited for economic gain[13]; $b$. Economic Resource Conflict, refers to conflict due to limited resources to improve the economy and the low capability of the governance in making policies that cause conflicts of many actors including the community, corporation and government; c. Identity Conflict, occurs when the opposing parties place their own identity contrary to the identity of other parties[14]; d. Electoral conflict, refers to random or organized actions to intimidate, do physical damage, threaten or violate political stakeholders in an effort to determine, delay or otherwise influence the electoral process[15]; e. Governance Conflict, refers to conflicts that result from bad governance so that the process of policy making and its implementation does not benefit the governed public[16]; f. Others, to categorize some recorded events as a new types of conflict.

To understand women's vulnerability in conflict, this study need to use a framework to analyze the role or position of women during and after the conflict. According to some literatures, women's roles and positions can be fluid and interchangeable, due to the social structures and relationships that determine what women do or can do in these conditions.[17] Some other literatures also see the negotiating dimensions of women's behavior that highlight women's agency so that women can become dominant actors in resolving conflicts. This study classified women's roles as : perpetrators, victims, and agent of peace or peacemakers.

\section{RESULT AND DISCUSSION}

In accordance with observation through media monitoring, started from 2016 until 2018, 228 social conflicts happened in East Java:

Chart 2: Number of Conflict based on the Type of Conflict in East Java 2016-2018

\begin{tabular}{l|c}
\hline \multicolumn{1}{c|}{ Jenis Konflik } & Number of Incident \\
\hline Natural Resources Conflict & 58 \\
\hline
\end{tabular}




\begin{tabular}{l|c}
\hline Economic Resources Conflict & 35 \\
\hline Electoral Conflict & 9 \\
\hline Identity Conflict & 31 \\
\hline Governance Conflict & 66 \\
\hline Other Conflicts & 29 \\
\hline \multicolumn{1}{c|}{ Total Events } & $\mathbf{2 2 8}$ \\
\hline
\end{tabular}

From the table above, it can be seen that the most common type of social conflict in 2016-2018 was governance conflicts with 66 events. Governance Conflict is caused by poor governance quality, especially about corruption level and weak law enforcement. Moreover, another aspect related to governance conflict is conflict in the education sector. The second position was natural resources conflict with 58 events, dominated by land disputes, ranging from land ownership conflicts, to conflicts over eviction of houses or land use for public purposes such as highway, a classic agrarian conflict that often arise in the development process. Natural resource conflicts were also tinged with mining and environmental conflicts, reclamation, pollution from industrial waste, and water scarcity due to the construction of a factory. Most of the conflicts that can be recorded in this study were conflicts over exploitation of natural resources. Conflicts involved actors between communities and corporations with high intensities of violence. The following was other conflicts in the third position with 36 events. Conflicts over economic resources emerged with 35 events dominated by industrial conflicts regarding decent wages and salaries, restrictions on the right of association, and rejection of layoffs. Another noticeable economic resource conflict were the conflicts between conventional public and online transportation. The identity conflicts recorded with 31 events dominated by conflicts and clashes between mass organizations, sports supporters, and the most interesting is the conflict between martial arts groups. Electoral conflict had the lowest number of events. However, there was a tendency for the increasing electoral disputes at the village level. This is an indication that conflict has touched the lowest scale of political contestation, and anticipatory steps are needed to prevent the conflict from spreading to other villages in East Java.

In order to assess the women's vulnerability in East Java, this research aimed to underline the role and position of women during conflict. The chart below showed a trend that demonstrates the role and position of women in the social conflict in East Java throughout 2016-2019:

Picture 3: Women and Social Conflict in East Java 2016-2018

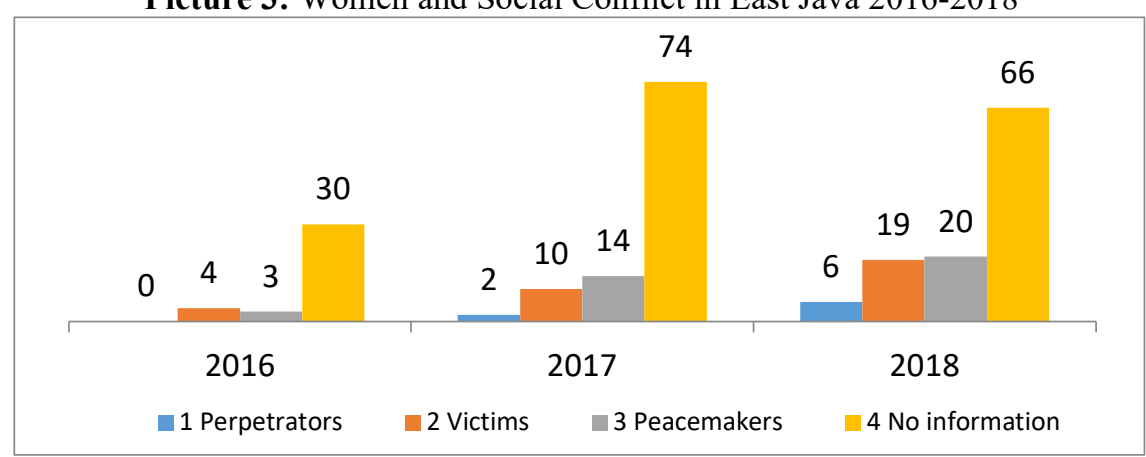

The dataset above shows that women involvement in the social conflict in East Java within 2016-2018 increases significantly, whether as perpetrators, as victims or as peacemakers. The chart above shows that women recorded as perpetrators increased from in 0 
(2016) to in 2 events ( 2017) and in 6 events (2018). As victims, women were recorded in 4 events (2016) to 10 events (2017) and 19 events (2018). As peacemakers, women recorded in 3 events (2016) to 14 events (2017) to 20 events (2018). of the 228 recorded events, 170 did not indicate women's involvement in the conflict. This does not necessarily indicate the lack of involvement of women in conflict. On the contrary, this might indicate that the media has no gender sensitivity in framing the conflicts.

The detailed findings underline women's involvement within each type of conflict in East Java as follows :

Picture 4: Women's Role in Conflict in East Java 2016-2018 Based on Type of Conflict

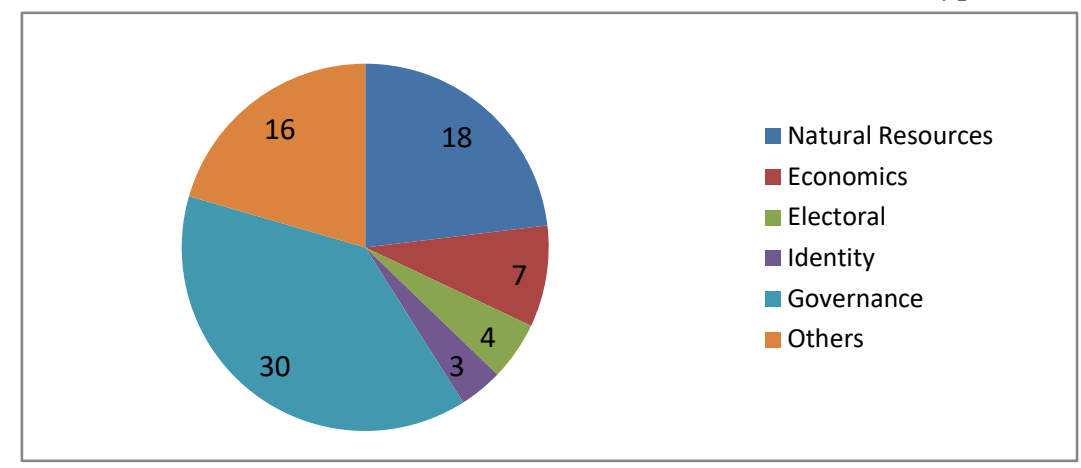

The chart above shows that women recorded mostly involved in governance conflicts with 30 events. Followed by natural resource conflicts where women were recorded in 18 events. Next is other conflicts where women were recorded in 16 events, then economic resource conflicts in 7 events, electoral in 4 events and finally the least appeared in identity conflict with 3 events.

Furthermore, the results of this study also show the following types of women's involvement based on the type of conflict:

Picture 4: Women's Involvement in Conflict in East Java 2016-2018 Based on Type of Conflict and Type of Role

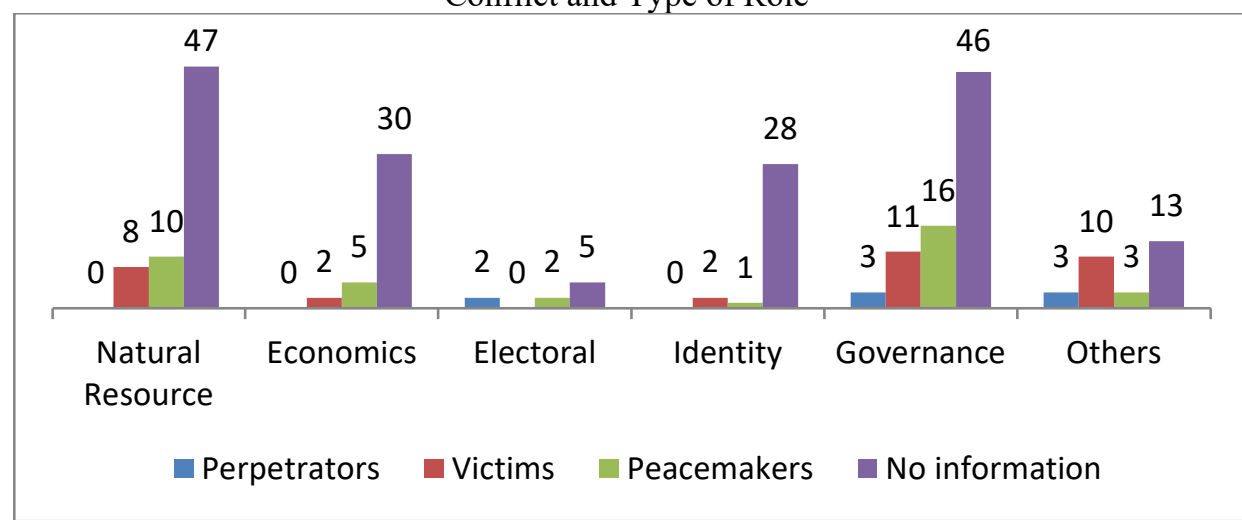

The chart above highlights women significantly involved in governance conflicts. Within this category, women involved in all roles of the conflict. In natural resource conflicts, women could not be found as perpetrators, but the figure was quite high as victims and as 
peacemakers. The trend also signified identical patterns with economic resources conflict and natural resources conflicts. Overall, the women's involvement indicated an insignificant number in the conflict-related to identity and electoral conflicts. The greatest number of women appearing as victims was in other types of conflict with 10 events. In this type of conflict women also emerged as perpetrators with the same number of events as governance conflicts, where as peacemakers only appeared in 3 events. What needs to be highlighted in other conflict categories was the recording of a series of bombing events in Surabaya in medio of May 2018. Although it is difficult to categorize these events as conflict events, the impact of these events on women was quite significant. Women in these incidents were not only victims, but also perpetrators of violence.

\section{CONCLUSIONS}

In conclusion, the research found that East Java may still become a vulnerable region to conflict according to the data obtain in 2016-2018. Social conflict in East Java showed an increasing trend, as well as women's involvement in the conflict. The most intense conflict in East Java was governance conflict and so did the women involvement. Concrete policies in responding to high-level women vulnerability in East Java is highly needed. The role of women as peacemakers dominated by those who were victims in conflict. The women agency toward conflict resolution also indicated by the occurring of women political leaders in some cities in East Java. Therefore, it could be seen that East Java relatively have a positive attitude toward women agency in managing and responding conflict. The occurrence of women's political leadership will determine the future women agency toward conflicts in East Java. There is an indication that media does not have gender sensitivity in capturing and reporting conflict. Therefore, further research on this issue is important for the future research agenda.

\section{REFERENCES}

[1] Kementerian Koordinator Pembangunan Manusia dan Kebudayaan, "Sistem Nasional Pemantauan Kekerasan Indonesia (SNPK),” http://snpk.kemenkopmk.go.id/. [Online]. Available: http://snpk.kemenkopmk.go.id/.

[2] B. Hermawan, "Indeks Demokrasi Indonesia Terus Menurun Sejak 2015," republika.co.id, 2017.

[3] A. Fatah, "Konsolidasi Komunal sebagai Mitigasi Konflik Agama di Jawa Timur," Lentera Huk., 2018.

[4] G. C. for D. C. of the A. F. (DCAF) and I. for D. S. and P. S. (IDSPS), "Almanak Hak Asasi Manusia di Sektor Keamanan Indonesia 2014," Jakarta, 2014.

[5] Presiden RI, Perpres No. 18 Tahun 2014 tentang Perlindungan dan Pemberdayaan Perempuan dan Anak Dalam Konflik Sosial. 2014.

[6] Governor of East Java, Keputusan Gubernur Jawa Timur No. 188/238/KPTS/013/2015 tentang Tim Terpadu Penanganan Konflik Sosial. 2015.

[7] W. J. Comcowich, "Media Monitoring the Complete Guide: Everything you Wanted to Know About Media Monitoring, But Didn't Think to Ask," CyberAlert.Inc. [Online]. Available: http://www.cyberalert.com/downloads/media_monitoring_whitepaper.pdf. [Accessed: 21-Mar-2019].

[8] G. Miller, O. J. Bartos, and P. Wehr, "Using Conflict Theory," Contemp. Sociol., 2003. 
[9] R. H. Gault, R. E. Park, and E. W. Burgess, "Introduction to the Science of Sociology," J. Am. Inst. Crim. Law Criminol., 1922.

[10] R. W. Mack and R. C. Snyder, "The analysis of social conflict-toward an overview and synthesis," J. Conflict Resolut., 1957.

[11] P. Berger and T. Luckmann, "The social construction of reality," in Social Theory ReWired: New Connections to Classical and Contemporary Perspectives: Second Edition, 2016.

[12] A. Varshney, "Ethnic Conflict, the State, and Civil Society," in Ethnic conflict and civic life: Hindus and Muslims in India, 2003.

[13] United Nations Environment Programme, "Natural resources and conflict: a guide for mediation practitioners," 2015.

[14] C. Malek, "Identity (Inter-Group) Conflict, Beyond Intractability," beyondintractability.org. [Online]. Available: https://www.beyondintractability.org/coreknowledge/identity-issues. [Accessed: 23Jul-2019].

[15] J. Fischer and IFES, "Electoral Conflict and Violence. A Strategy for Study and Prevention," IFES White Pap., 2002.

[16] H. Hegre and H. M. Nygård, "Governance and Conflict Relapse," J. Conflict Resolut., 2015.

[17] T. Bouta and G. Frerks, "Women's Roles in Conflict Prevention, Conflict Resolution and Post-Conflict Reconstruction," Encycl. Violence, Peace, Confl., 2002. 